\title{
Writing Maori English: Voices in Pounamu, Pounamu.
}

\author{
John MacAllister
}

Attempts to pin down the distinguishing features of Maori English have exercised linguists for a considerable period of time. Only a decade ago Benton $(1991,193)$ was able to conclude that, up to that time, 'the evidence was not strong enough to establish the existence of a Maori English dialect'. More recently, however, Bell (2000) has proposed that Maori English - which he refers to as Maori Vernacular English - could be identified through the cooccurrence of certain speech features, and Stubbe and Holmes (2000) have drawn attention to discourse features that signal ethnic identity in New Zealand English.

One characteristic of Maori English that, although acknowledged, has not yet received a great deal of attention is the influence of te reo Maori in the Maori English lexicon. Thompson (1990), in a small-scale study involving female pakeha subjects, demonstrated that those who knew some Maori language were more likely to use Maori words in appropriate English language contexts than those who did not. Kennedy (2001), in an analysis of the use of words of Maori origin in the Wellington Corpus of Spoken New Zealand English, found a significantly higher use of Maori words among Maori than among non-Maori. The implication of these two studies is that Maori lexical content is one feature that can be used to distinguish between Maori and Pākehā Englishes.

In this discussion, an examination of the Maori word content in the ten short stories that comprise the best-selling collection Pounamu, Pounamu is undertaken to establish whether or not such a feature is apparent in the work of a literary writer.

\section{Pounamu, Pounamu}

This collection of short stories by Witi Ihimaera appeared in 1972. It received considerable publicity as being the first published volume of stories by a Maori writer, and achieved best-selling status in New Zealand, with annual reprints for a number of years following first publication. Several of the stories became staples of classroom teaching and at least one story was transformed into television drama. In addition, Pounamu, Pounamu won third prize in the 1973 Wattie Book of the Year Awards.

Ihimaera has been credited, in this collection, with opening pakeha eyes to Maoridom; for the pakeha, it has been claimed, the stories 'carried something of

Kōtare 4, no. 1 (2001), pp. 46-54. 
the force of revelation' (Arvidson, 118). That claim is almost certainly true. The interest here, however, is in examining how Ihimaera differentiated between Maori and pakeha voices.

\section{The Stories}

Pounamu, Pounamu consists of ten stories of varying length, from 'A Game of Cards' and 'In Search of the Emerald City', with five pages apiece, to the thirtysix-page 'One Summer Morning'. Seven of the stories are narrated in the firstperson by a Maori narrator. Two are third-person narratives through the eyes of a Maori character. The remaining story is told from a pakeha point of view.

Although written in English, the collection has a distinctive Maori language content. Te reo is present in various forms - as examples of code-switching, of code-mixing, and of borrowing into English. In the following analysis only lexical units that appear to be borrowings are counted; that is, as a rule of thumb, the meaning is clear within the context. Thus, for instance, the lines from a song:

Me he manurere, aue,

Kua rere tito, moenga ... [p. 36]

are excluded from the discussion, but, in the following example:

He motioned me to a cupboard and brought out a wakahuia, a small carved box. [p. 37]

the word wakahuia is included. Usually such lexical units are single words, as a layperson would understand the term 'word', although occasionally, and particularly with greetings such as haere max, a lexical unit may consist of more than one 'word'; the term 'word' is used here to describe any such lexical unit.

The words were identified through a manual search of the stories. A later follow-up search found that no Maori word types had been missed, and there was an insignificant change in the number of tokens of the highest frequency items.

The discussion that follows excludes personal and place names, for while they add a Maori flavour to the stories, the use of such words is determined by setting rather than any inherent characteristic of the language variety.

Kōtare 4, no. 1 (2001), pp. 46-54. 
Also excluded from the discussion are lexical features that may be thought of as peculiar to Maori English. These include the use of Nanny and auntie, and of the tag ay, as in this example:

What you think I had all these kids for, ay? [p. 1]

\section{The Pakeha Point of View}

The sole story narrated from a pakeha viewpoint is 'The Other Side of the Fence'. Apart from place and person names, only four words of Maori origin occur in this 21-page story. One of those four types - Maori - is found 13 times. The other three words - hangi, puha, kina - occur once each.

\section{The Third Person Narrative}

The longest story in the collection, 'One Summer Morning', is narrated in the third person from the perspective of a Maori character, the boy Hema Tipene. The story contains 25 Maori word tokens other than place and person names. Only four types have more than one occurrence, those four being:

$\begin{array}{ll}\text { kai } & \text { [8 tokens] } \\ \text { pakeha } & \text { [3 tokens] } \\ \text { Maori } & \text { [2 tokens] } \\ \text { pae kare } & \text { [2 tokens] }\end{array}$

On the other hand, the second story in this category, 'The Whale', a lament for a vanishing way of life in a changing world, has the greatest density of Maori words of any of the stories in the collection. 109 Maori words are found in its eight pages, which makes 'The Whale' somewhat problematic in terms of this discussion, for its narrative structure is not first-person yet it has the richest Maori lexical content.

The high frequency of Maori words is partly explained by a narrative style that is often rhythmic and repetitive:

This kaumatua, his eyes dim.

[p. 115]

He cannot help it, this kaumatua

[p. 118]

This kaumatua, the memory falls away from him . [p. 121]

It is also explained, in part, by the sometimes didactic nature of the story, describing, for example, the components of the meeting house - koruru, maihi, tahuhu, heke, wheku, tukutuku, koivhaiwhai - these types contribute 12 tokens. Further, there is an emphasis on the distinctiveness of Maori culture Maoritanga (2 tokens), Maori (17), pakeha (5).

Kōtare 4, no. 1 (2001), pp. 46-54. 
The language used in 'The Whale' is clearly not Pakeha English. The question arises, however: is it a realistic representation of Maori English? While readers of the story will form their own opinions about this, it is unlikely that many will feel it bears much resemblance to the vernacular, or to the language used in the stories with first person narrators. Rather, the language of 'The Whale' seems to be a literary style, replete with Maori words to conjure the vanishing way of life it mourns.

\section{The Stories with First Person Narrators}

As a general rule, the seven remaining stories use a greater number and a greater variety of Maori words than those not narrated in the first person by a Maori character. Some idea of this can be gained from the following table, which shows the page length and the number of Maori words in each story.

STORY TITLE

A Game of Cards

Beginning of the Tournament 7

The Makutu on Mrs Jones 16

Fire on Greenstone

In Search of the Emerald City 5

The Child

Tangi

\section{PAGE LENGTH NO. MAORI WORDS}

523

3

52

41

46

44

35

It is perhaps worth again emphasising that these are words other than person and place names.

The clear conclusion that can be drawn from this table is that words of Maori origin are a significantly greater presence in those stories narrated in the firstperson by Maori characters, than those with other forms of narration.

The one exception to this statement is 'Beginning of the Tournament', with only three Maori word tokens, the types Maori and pakeha. This story, while narrated by a Maori character, is essentially the story of Jerry, a pakeha visitor to a Maori hockey tournament. In this respect 'Beginning of the Tournament' is closer to 'The Other Side of the Fence' than to the other stories in the collection. It is presumably because the narrative focus is on Jerry that the occurrence of Maori words in this story is so low; it could be that the Maori characters, interacting with an outsider, are adjusting their language accordingly.

Kōtare 4, no. 1 (2001), pp. 46-54. 


\section{The Nature of the Borrowings}

The sheer number of borrowings present in the collection is not in itself necessarily meaningful. Such borrowings could, for example, be contributed by the names of flora and fauna, which may impart a New Zealand feel to the stories but have no cultural import. Therefore the nature of the borrowings needs to be examined.

The types with the highest frequency in the collection, and found in more than one story, are:

\begin{tabular}{|c|c|}
\hline & kens] \\
\hline mokopur & {$[36 \mathrm{t}$} \\
\hline whanau & {$[23 \mathrm{t}$} \\
\hline pakeha & [18 tokens] \\
\hline tokotoko & [16 tokens] \\
\hline marae & [15 tokens] \\
\hline каi & [13 tokens] \\
\hline aue & [12 tokens] \\
\hline naere & [10 toke \\
\hline
\end{tabular}

In addition to these 9 types, a further three occur 10 or more times, but each is confined to just one story. They are:

makutu [20 tokens]

haere ra [13 tokens]

aroha [11 tokens]

These high frequency word types chiefly fall into the categories of family (mokopuna, whanau), social relationships (marae, aroha, haere mai, haere ra), and beliefs (makutu). This lexical emphasis suggests that Ihimaera reached well beyond the world of pa, poi and haka familiar to pakeha and revealed a previously unsuspected face of Maoridom to his readers.

It is worth noting that the borrowings found in 'The Other Side of the Fence' belong to the familiar rather than the unsuspected, as do over half the types in 'The Whale'.

\section{The Treatment of the Borrowings}

The fact that approximately one-third of the tokens of the type Maori were found in the two stories with a pakeha narrative focus is revealing. In those stories, and particularly in 'The Other Side of the Fence', Maori are being marked as different. In the remaining stories, however, this is not the case. Here Maori 
represent the norm. As the stories are about Maori people, in Maori communities, and written by a Maori author, this is perhaps not surprising, although at the time of publication it no doubt struck many readers with 'something of the force of revelation' (Arvidson, 118).

However, the target readership for the stories was, inevitably, predominantly pakeha. Therefore, there had to be an acknowledgement that many of the borrowings used in the stories - the borrowings that helped create the distinctively Maori voices — would be unknown to the readers. To accommodate this, Ihimaera skilfully wove glosses, and particularly embedded glosses (Macalister, 2000: 76) into his stories, as in this example from 'The Whale':

His tokotoko, his walking stick, it supported him as he approached the door.

It is noteworthy that the borrowings, although glossed to aid understanding, are not otherwise marked as being imports into English. They are not, for example, italicised or encased in inverted commas. They are also treated, morphologically, as comparable English words would be. Note the plural $-s$ in this example from 'A Game of Cards'.

She liked her mokopunas, but not for too long.

\section{Conclusion}

Pounamu, Pounamu was, on a number of levels, a landmark publication. This examination of the use of Maori words in the stories has sought to establish how the author successfully created Maori voices. The significantly larger presence of borrowings in the stories narrated by Maori in the first-person suggests that lexical choice is a distinguishing feature of Maori English, just as the relative absence of such borrowings characterises Pakeha English. It was not, however, numerical presence alone that created recog-nisably Maori voices, but also the nature of the borrowings, drawing as they did on the lexicons of the family, of social relationships, and of belief systems.

\section{Works Cited}

- Arvidson, Ken. 'Aspects of Contemporary Maori Writing in English.' Dirty Silence: Aspects of Language and Literature in New Zealand. Ed. 
Graham McGregor and Mark Williams. Auckland: Oxford University Press, 1991. Pp. 117-28.

- Bell, Allan. 'Maori and Pakeha English: a case study.' New Zealand English.

Ed. Allan Bell and Koenraad Kuiper. Wellington: Victoria University Press, 2000. Pp. 221-48.

- Benton, Richard. 'Maori English: a New Zealand myth?' English around the World: Sociolinguistic Perspectives. Ed. Jenny Cheshire. Cambridge: Cambridge University Press, 1991. Pp. 187-99.

- Ihimaera, Witi. Poiinamu, Pounatnu. Auckland: Heinemann, 1972.

- Kennedy, Graeme. 'Lexical Borrowing from Maori in New Zealand English.' Who's Centric Nozo? The Present State of Post-Colonial Englishes. Ed. Bruce Moore. Melbourne: Oxford University Press, 2001. Pp. 59-81.

- Macalister, John. 'Reflections on Lexical Borrowing and Code-Switching in New Zealand English.' Kotare: New Zealand Notes and Queries 3, 2 (November, 2000): $73-79$.

- Stubbe, Maria \& Janet Holmes. 'Talking Maori or Pakeha in English: signalling identity in discourse.' New Zealand English. Ed. Allan Bell and Koenraad Kuiper. Wellington: Victoria University Press, 2000. Pp. 249-78.

- Thompson, Wendy. 'Attitudes to Maori and the use of Maori lexical items in English.' Wellington Working Papers in Linguistics 1 (1990): 37 - 46.

Kōtare 4, no. 1 (2001), pp. 46-54. 